\title{
Structure Simulation Analysis of Xin'anpu Trench-buried Inverted Siphon
}

\author{
Ji Dongyu \\ Hunan Urban Construction College \\ Xiangtan, China \\ hnjdy@126.com
}

\author{
Yang Hao \\ North China University of Water Resources and \\ Electric Power \\ Zhengzhou, China \\ 1359396457@qq.com
}

\begin{abstract}
The inverted siphon straw is pressure water pipeline which convey cannel water through valley, river, road, depression, or other channels, and it is a kind of channel cross building, is one of the most important buildings in irrigation engineering. In order to the stress and deformation distribution of the inverted siphon structure have a clear understanding, studies the stress characteristics of inverted siphon structure. This paper uses the general finite element calculation software of Xin'an Pu ditch burying of inverted siphon structure do the analysis by three dimensional finite element simulation, studied the stress an deformation distribution in the construction and operation cases of inverted siphon structure, provides a useful reference for the design and construction of reinforced concrete trench buried type of inverted siphon structure. The analysis results show that, Xin'an Pu inverted siphon project using reinforced concrete trench buried structure is safe, economic, inverted siphon Straw in the construction and operation process the stress and deformation are small, and can satisfy the engineering requirements.
\end{abstract}

Keywords-Inverted siphon pipe; Finite element method; Simulation analysis; Circumferential stress; Radial deformation.

\section{Project OVERVIEW}

Xin'an Pu inverted siphon is located in the Dazhen irrigation areas in Hunan Province, the inverted siphon design flow velocity is $7.5 \mathrm{~m}^{3} / \mathrm{s}$, the flow rate is $2.39 \mathrm{~m} / \mathrm{s}$, minimum head is $78 \mathrm{~m}$, design head is $90 \mathrm{~m}$, the head loss is $2.88 \mathrm{~m}$, inverted siphon pipe length is $781.5 \mathrm{~m}[1]$. Inverted siphon straw with single hole channel buried inverted siphon tube, pipe diameter is $2 \mathrm{~m}$, wall thickness is $0.13 \mathrm{~m}$, pipe body using one stage of prestressed reinforced concrete pipe, concrete strength grade of C30, steel strength grade is grade II[2].

\section{STRUCTURE CALCULATION MODEL}

\section{A. Material Parameters.}

Xin'an $\mathrm{Pu}$ inverted siphon project uses the reinforced concrete ditch buried structure[3], inverted siphon and cushion concrete strength grade of $\mathrm{C} 30$, elastic modulus $E_{1}=30 \mathrm{GPa}$, Poisson ratio $\quad \mu_{1}=0.167, \quad$ bulk density $\gamma_{1}=25 \mathrm{kN} / \mathrm{m}^{3}$. Steel strength grade is grade II, elastic modulus $E_{\mathrm{s}}=200 \mathrm{GPa}$, poisson's ratio $\mu_{\mathrm{s}}=0.28[4]$. Calculation of the simulation model of the horizontal segment foundation is silty heavy loam[5], the material compression modulus $E_{2}=20 \mathrm{MPa}$, poisson's ratio $\mu_{2}=0.30$.

\section{B. Computational Model.}

In the numerical siphon structure, using 8 element SOLID65 to simulation of inverted nodes isoparametric brick simulate the inverted siphon straw and cushion, this unit is a special unit to simulation concrete or rock, and it can set for the volume reinforcement ratio of concrete structure in each direction or the anisotropic properties of $\operatorname{rock}[6]$. The 8 nodes isoparametric brick element SOLID45 is used to simulate foundation[7]. The computing model will do the simulation analysis for the horizontal section of Xin'an $\mathrm{Pu}$ inverted siphon, the finite element calculation model as shown in Fig.1.

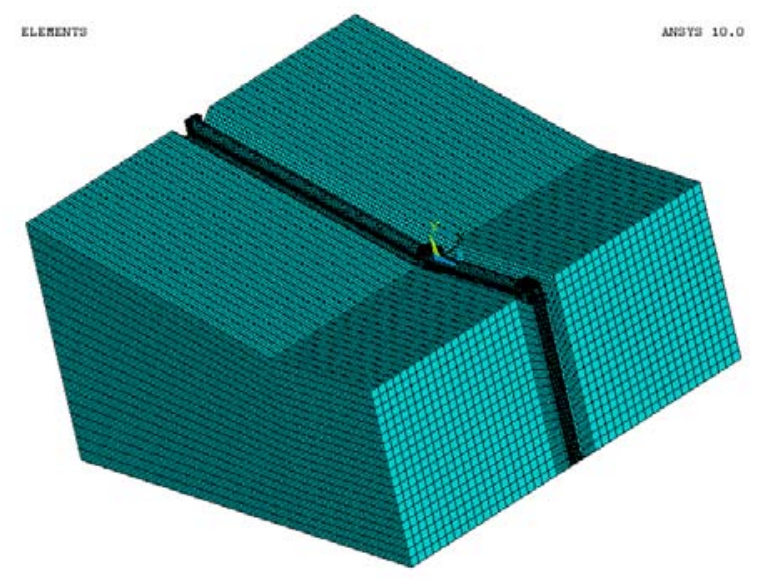

Figure 1. Finite element calculation model of inverted siphon structure

\section{The Calculation Case.}

The horizontal segment of Xin'an $\mathrm{Pu}$ inverted siphon design head $90 \mathrm{~m}$, minimum head $78.2 \mathrm{~m}$,simulation calculation mainly consider 4 calculating cases[8]: case 1 : weight(construction conditions), case 2: weight and prestressed (construction conditions), case 3: weight, prestressed and minimum head (operating case), case 4 : weight, prestressed and design head (operating case).

\section{ANAL YSIS OF THE CALCULATED RESULTS}

\section{A Stress Analysis.}

By doing the finite element simulation analysis of Xin'an $\mathrm{Pu}$ trench buried inverted siphon structure, the first principal stress is got in each case, the first principal stress and transverse stress contour of inverted siphon are shown in Fig. 2 to Fig.9. 


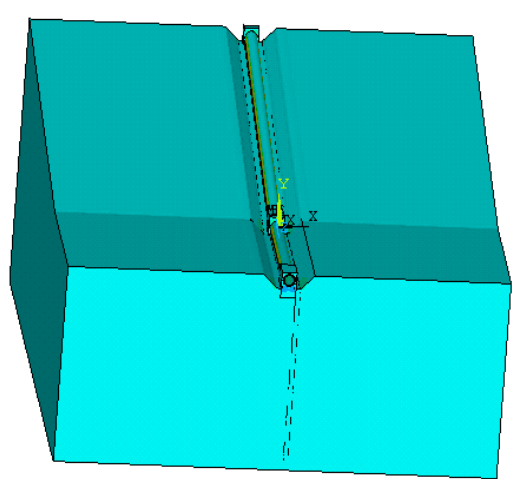

Figure 2. The first principal stress cloud map of inverted siphon under case $1(\mathrm{~Pa})$

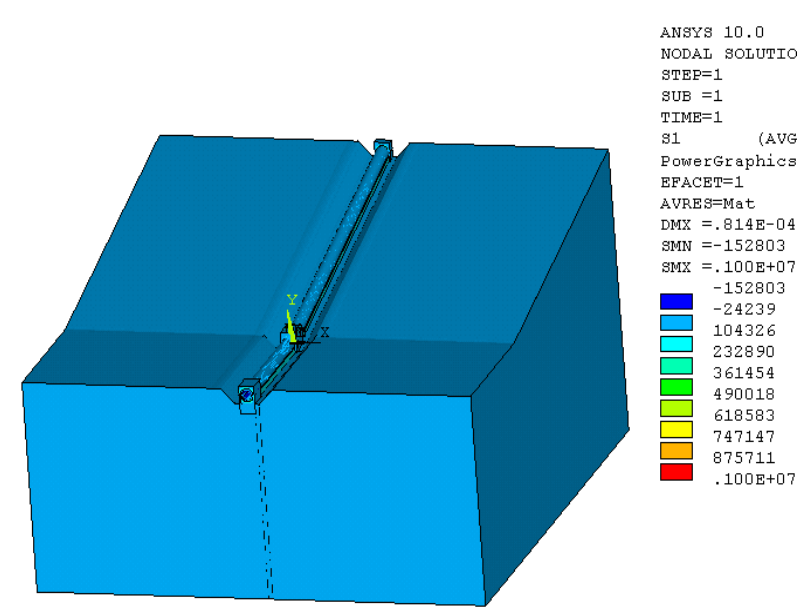

Figure 3. The first principal stress cloud map of inverted siphon under case $2(\mathrm{~Pa})$

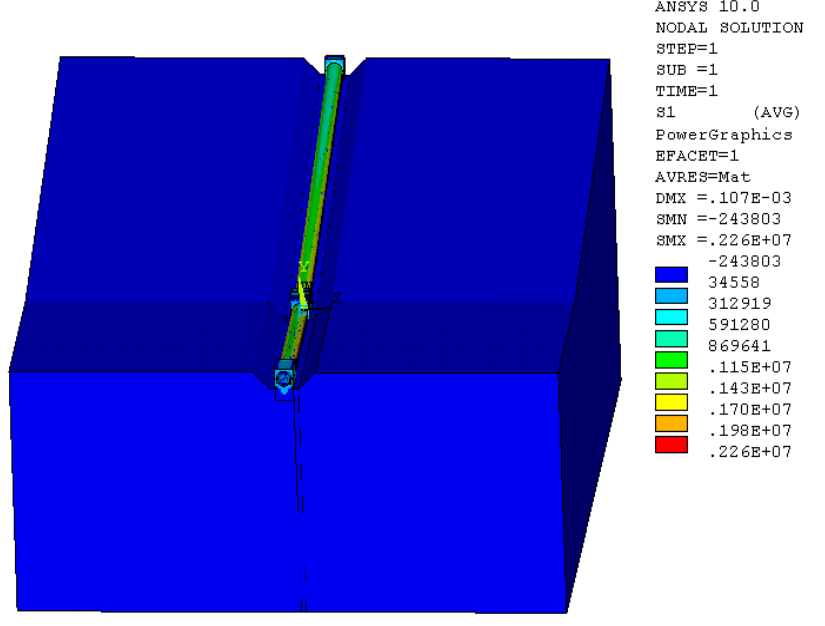

Figure 4. The first principal stress cloud map of inverted siphon under case $3(\mathrm{~Pa})$
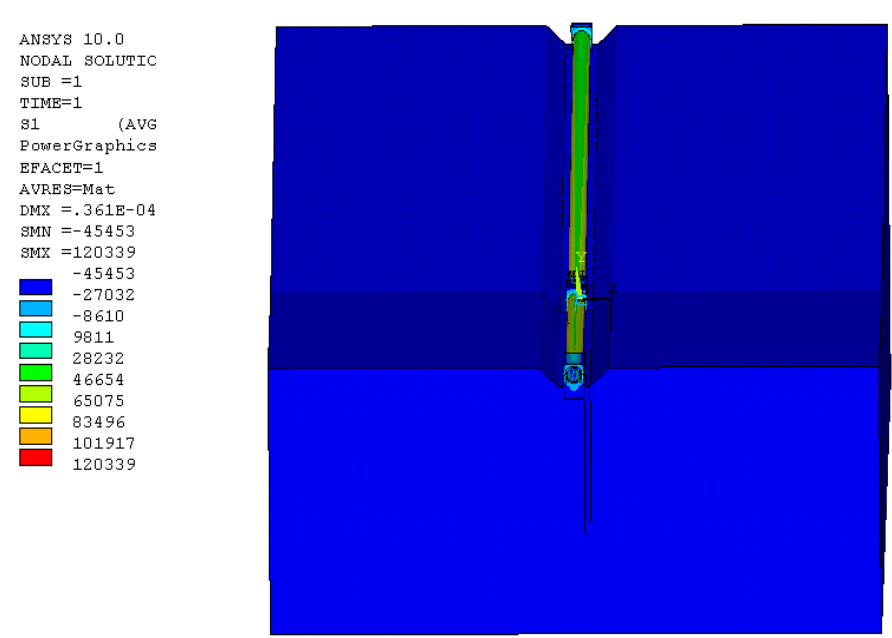

ANSYS 10.0

NODAI SOLUTION

STEP $=1$

SUB $=1$
TTME $=1$

S1 (AVG)

PowerGraphice
EFACET $=1$

AVRE $S=$ Mat

DMX $=.147 \mathrm{E}-03$

SMN $=-321916$

$\mathrm{SMX}=.322 \mathrm{E}+07$

$-32191$

71876

465669
859462
$.125 \mathrm{E}+07$

$.125 \mathrm{E}+07$
$.165 \mathrm{E}+07$

$.165 \mathrm{E}+07$

$.243 \mathrm{E}+07$

$.283 \mathrm{E}+07$ $.283 \mathrm{E}+07$

Figure 5. The first principal stress cloud map of inverted siphon under case $4(\mathrm{~Pa})$

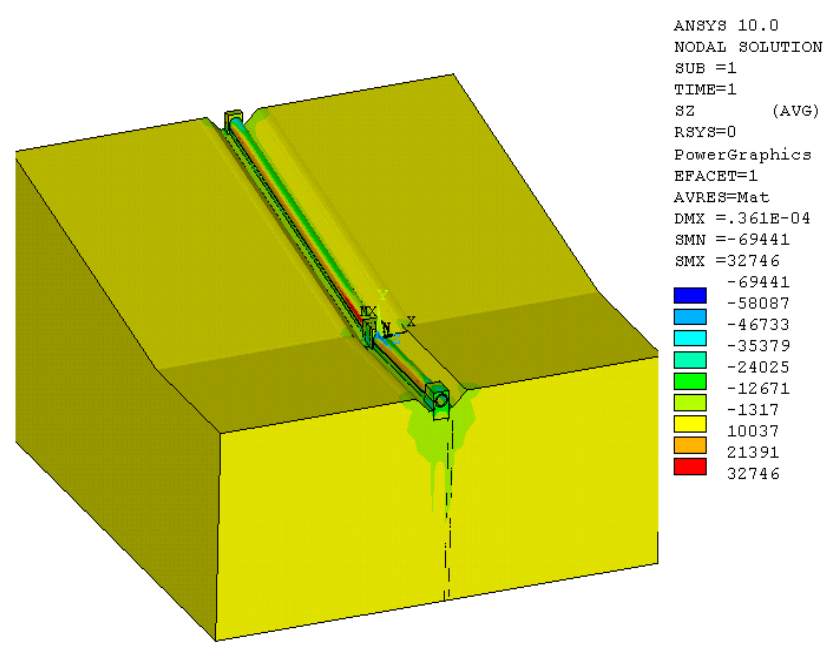

Figure 6. The axial stress cloud map of inverted siphon under case $1(\mathrm{~Pa})$

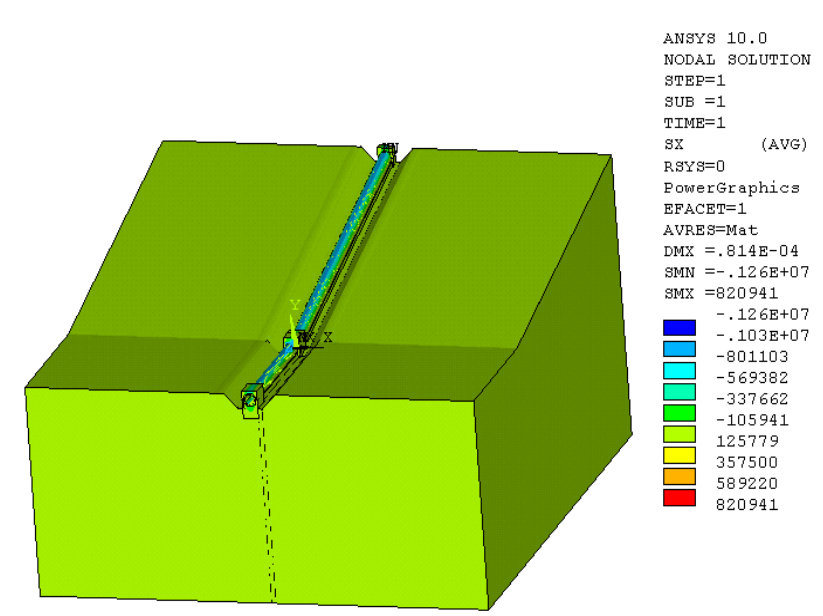

Figure 7. The transverse stress cloud map of inverted siphon under case $2(\mathrm{~Pa})$ 


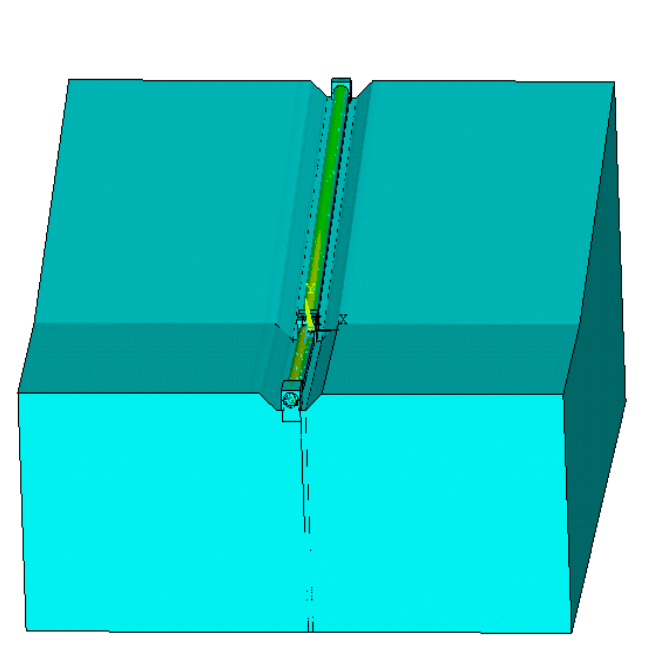

ANSYS 10.0 NODAL SOLUTION $\mathrm{STEP}=$

SUB $=$

TIME $=$

RSYS $=0$

PowerGraphic

EFACET $=1$

DMX $=.107 \mathrm{E}-03$

SMN $=-818065$

-818065
-475897
-133729

$-133729$

208438
550606

550606
892774

892774
$.123 \mathrm{E}+07$

$.158 \mathrm{E}+07$

$.192 \mathrm{E}+07$

Figure 8 . The transverse stress cloud map of inverted siphon under case $3(\mathrm{~Pa})$

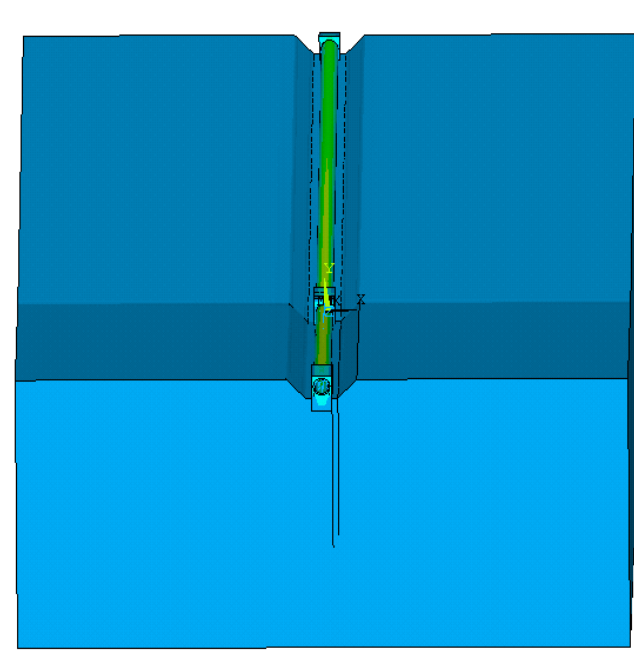

ANSYS 10.0

NODAL SOLUTIC

STEP $=1$

SUB $=1$

$\operatorname{TIME}_{\mathrm{SX}}^{\mathrm{TI}}$ (AVG

Sx.

RSYS $=0$
PowerGraphics

PowerGraph
EFACET $=1$

ANY $=1475-03$

$\begin{aligned} \text { DMX } & =.147 \mathrm{E}-03 \\ \text { SMN } & =-886172\end{aligned}$

SMN $=-886172$
SMX $=.322 \mathrm{E}+07$

$-886172$

-429685
26803

26803
483290

939778

$.140 \mathrm{E}+07$

$185 \mathrm{E}+07$

$.231 \mathrm{E}+07$

$277 \mathrm{E}+07$

Figure 9. The transverse stress cloud map of

inverted siphon under case $4(\mathrm{~Pa})$

From Fig. 2 to Fig. 9 it can be seen that in the case 4 and 5, the first principal stress maximum value of inverted siphon appeared in the middle section of thehorizontal section at the top of the pipe, which is mainly due to lower stiffness at the top of inverted siphontube, under the internal water pressure appear larger tensile stress at the top of the pipe inner surface, from the bottom of the pipe internal surface to the outward, its first principal stress decreases gradually. In case 1 the maximum principal stress of inverted siphon is $0.12 \mathrm{MPa}$, in case 2 the maximum principal stress of inverted siphon is $1.00 \mathrm{MPa}$ In case 3 the maximum principal stress of inverted siphon is $2.26 \mathrm{MPa}$, in case 4 the maximum principal stress of inverted siphon is $3.22 \mathrm{MPa}$. At the junction of inverted siphon and concrete cushion the stress distribution is more complex and drastic change, this is mainly because there was sharp which can produce the phenomenon of stress concentration[9]. In construction the sharp can be smooth or reserved expansion joints, which can ease the stress concentration problems here[10].

\section{B Deformation Analysis.}

By doing the finite element simulation analysis of Xin'an Pu trench buried inverted siphon structure, the total displacement is got in each case, the total displacement contour of inverted siphon are shown in Fig.10 to Fig. 13.

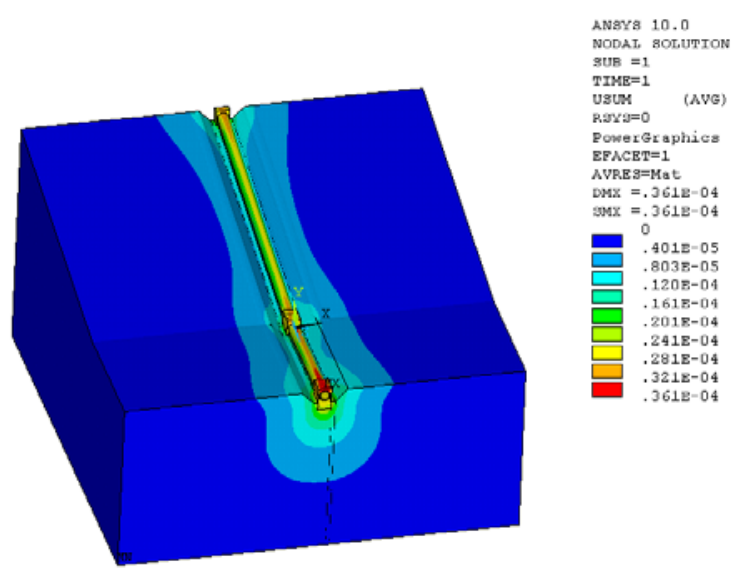

Figure 10. The total displacement cloud map of inverted siphon under case 1 $(\mathrm{Pa})$

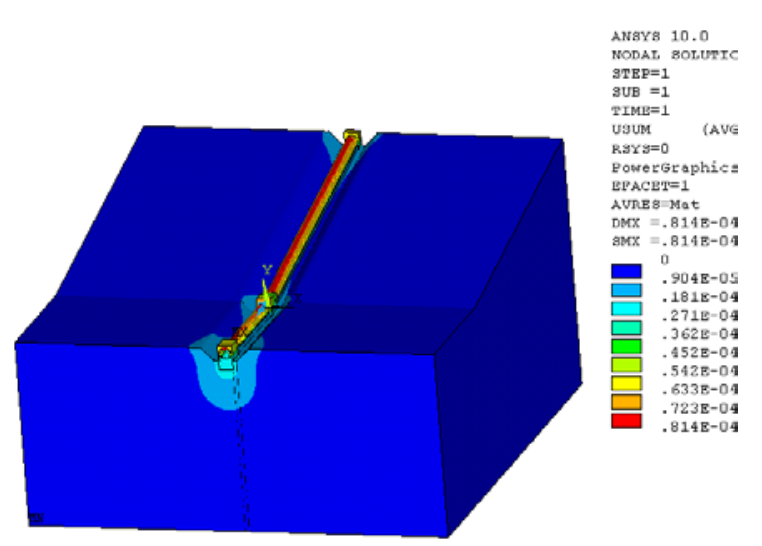

Figure 11. The total displacement cloud map of inverted siphon under case 2( $\mathrm{Pa})$

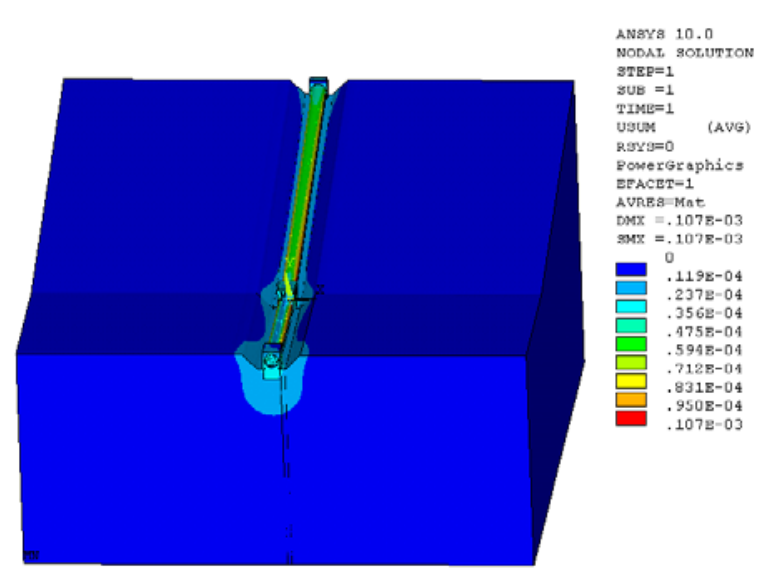

Figure 12. The total displacement cloud map of inverted siphon under case $3(\mathrm{~Pa})$ 


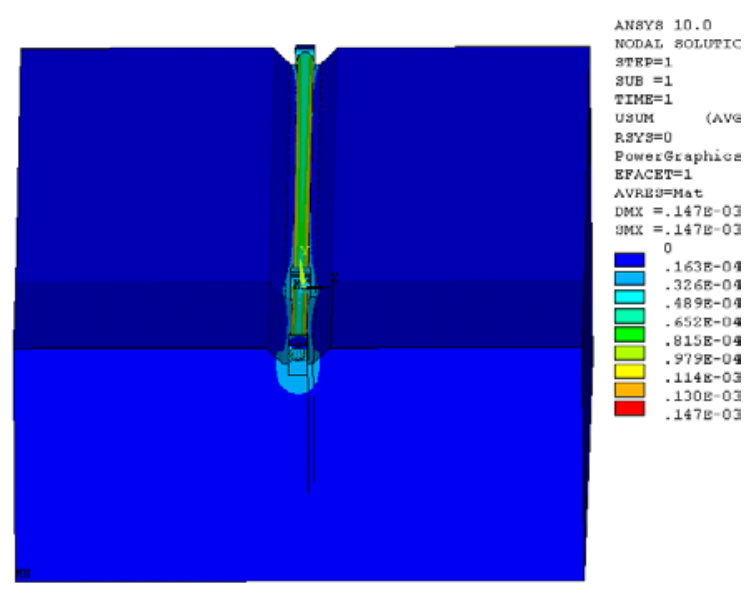

Figure 13. The total displacement cloud map of inverted siphon under case $4(\mathrm{~Pa})$

From Fig.10 to Fig.13, We can see that in the each case the total displacement of inverted siphon structure is small, and the inverted siphon structure mainly appears vertical displacement. In case 1 the maximum total displacement value of inverted siphon structure is $0.04 \mathrm{~mm}$, the maximum total displacement value of inverted siphon structure is $0.08 \mathrm{~mm}$ in case 2 , the maximum total displacement value of inverted siphon structure is $0.11 \mathrm{~mm}$ in case 3 , the maximum total displacement value of inverted siphon structure is $0.15 \mathrm{~mm}$ in case 4.

\section{SUMMARY}

The analysis results show that the Xin'an Pu inverted siphon project using reinforced concrete trench buried structure is safe, economic, the stress and deformation of inverted siphon in the construction and operation process are small, and it can satisfy the engineering requirement.

\section{REFERENCE}

[1] Xiaopei Sun,Xiaoling Wang,Ruirui Sun et al. Numerical Simulation for Water Conveyance of Inverted Siphon [C]. Advances in civil engineering II.2013:2407-2410.

[2] Juan Li,Zhenwei Mu,Lin $\mathrm{Li}$ et al. Numerical Simulation and Model Test on Hydraulic Characteristics of Long-Distance Inverted Siphon [C]. Advances in Hydrology and Hydraulic Engineering.2012:11121116 .

[3] Wenliang Ma,Weifang Zou. Three-dimensional finite element analysis of trench-buried inverted siphon structure [C]. 2012 7th International Conference on System of Systems Engineering. $2012: 380-382$.

[4] SL191-2008. Design Code for Hydraulic Concrete Structure[S] China Water Conservancy and Hydropower Press, 2008.

[5] Guangxin Li. Advanced Soil Mechanics [M]. Tsinghua University Press, 2005.

[6] Jianjing Jiang, Xinzheng Lu, Lieping Ye. Finite Element Analysis of Concrete Structures [M]. Tsinghua University Press, 2004.

[7] Xucheng Wang. Finite Element Method [M]. Tsinghua University Press, 2003.

[8] Huiying Li, Wenduo Tian, Haixin Yan. Inverted Siphons [M]. China Water Conservancy and Hydropower Press, 2006.

[9] Hui-Fang Xue,You Wang. Self-Vibration Characteristics of Plane Gate in Inverted Siphon Project C]. Advances in Intelligent Structure and Vibration Control.2012:62-66.

[10] Yan, Yibo,Liu, Guoqiang,Wang, Changde et al. Discharge Erro Analysis of Check Gate Combined with Inverted Siphon in a Canal Simulation System [C]. 2011 International Conference on Control, Automation and Systems Engineering. [v.1].2011:1-4. 